\title{
Pathologic motion patterns in patients with progressive pseudorheumatoid arthropathy of childhood
}

\author{
M Hartmann ${ }^{1 *}$, F Kreuzpointner ${ }^{1,2}$, R Haefner ${ }^{1}$, J-P Haas ${ }^{1}$ \\ From 18th Pediatric Rheumatology European Society (PReS) Congress \\ Bruges, Belgium. 14-18 September 2011
}

\section{Introduction}

Progressive pseudorheumatoid arthropathy of childhood (PPAC) is a specific subtype of spondyloepiphyseal dysplasie (SED) tarda. The skeletal disorder and is characterized by polyarthropathy of large and small joints. Typical signs are prominent epiphysis, progressive joint stiffness, muscle weakness and early fatigue [1]. Optimized physiotherapy is the only effective strategy to slow down the progress of functional disability.

\section{Aim}

Quantification of pathologic motion patterns during walking.

\section{Methods}

In a retrospective study eight adolescents suffering from PPAC (sex:female=1; male=7; age:14.6y; weight:50.0kg; size:1.42m; BMI:25) were compared with 20 healthy young person $(\mathrm{cg})$ (sex:female=17, male $=3$; age:17.9y; weight:53.8kg; size:1.59m; BMI:21). 3D-gaitanalysis was performed with infrared cameras and the Plug-in-Gait Model. Analyses focused spatio-temporal and kinematic parameters in the sagittal plane. Mann-Whitney-UTests $(\mathrm{p}<0.05)$ and correlation calculations (Pearson) between age, body-mass-index (BMI), kinematic and spatio-temporal-parameters were used for statistical analysis.

\section{Results}

Patients with PPAC walk very slow $(\mathrm{p}<0.001)$ with short step length $(\mathrm{p}<0.001)$ and broadened step width $(p<0.001)$. The foot off occurs noticeable late $(p<0.001)$. The kinematic data are highly significant different to the cg in pelvis, hip, knee and ankle. Especially the range of motion (ROM) in the hip, in the knee flexion (loading response) and extension (single support phase) as well as the ankle ROM (plantar flexion while push off) are decreased. Within the PPAC-group high negative correlations appear between BMI and ankle ROM (plantar flexion (push off)) $(r=-.860)$.

Table 1 Selection of kenematic results in pelvis, knee and ankle joint

\begin{tabular}{lccccc}
\hline & \multicolumn{2}{c}{ PPAC $(\mathbf{n}=\mathbf{8})$} & \multicolumn{2}{c}{ Control Group (n=20) } & M.-W. -U-Test Sign. (2-tailed) \\
\cline { 2 - 6 } & Median & $\mathbf{Q 2 5 / Q 7 5}$ & Median & Q25/Q75 & p $<$ 0.01 \\
\hline Pelvic tilt & 19.4 & $(15.1 / 21.6)$ & 11.2 & $(8.5 / 12.8)$ & $\mathrm{p}<0.001$ \\
\hline Hip ROM (Flex/Ext) & 32.0 & $(28.3 / 34.6)$ & 44.0 & $(42.0 / 46.4)$ & $\mathrm{p}<0.001$ \\
\hline Knee ROM (Flex, loading response) & 5.3 & $(4.4 / 6.9)$ & 11.6 & $(10.7 / 13.4)$ & $\mathrm{p}<0.001$ \\
\hline Knee ROM (Ext, single support1) & 2.5 & $(1.1 / 4.7)$ & 15.4 & $(13.6 / 17.8)$ & $\mathrm{p}<0.001$ \\
\hline Ankle ROM (Plan-Flex, push off) & 12.8 & $(11.3 / 13.0)$ & 29.7 & $(26.8 / 35.5)$ & $\mathrm{p}<0.001$ \\
\hline
\end{tabular}

'German Center for Pediatric and Adolescent Rheumatology, Garmisch-

Partenkirchen

Full list of author information is available at the end of the article 


\section{Conclusion}

The results are determined by very small ROM in the lower limb due to distinctive joint stiffness and muscle weakness. The effects of muscular weakness are intensified by high body weight.

The use of 3D-gaitanalysis is a helpful tool to individualize functional treatment to decelerate the progressive joint destruction in the lower limb.

\section{Acknowledgements}

The authors wish to thank the German foundation for children's rheumatism for supporting this study.

\section{Author details}

${ }^{1}$ German Center for Pediatric and Adolescent Rheumatology, GarmischPartenkirchen. ${ }^{2}$ Department of Biomechanics in Sports, Technische Universität München.

Published: 14 September 2011

\section{Reference}

1. Kozlowski K, et al: Australasian Radiology. 1986, , 30: 244-250.

doi:10.1186/1546-0096-9-S1-P269

Cite this article as: Hartmann et al:: Pathologic motion patterns in

patients with progressive pseudorheumatoid arthropathy of childhood.

Pediatric Rheumatology 2011 9(Suppl 1):P269.

Submit your next manuscript to BioMed Central and take full advantage of:

- Convenient online submission

- Thorough peer review

- No space constraints or color figure charges

- Immediate publication on acceptance

- Inclusion in PubMed, CAS, Scopus and Google Scholar

- Research which is freely available for redistribution

Submit your manuscript at www.biomedcentral.com/submit
C Biomed Central 